\title{
DESAKRALISASI DAN DELEGITIMASI KONSEP KEPEMIMPINAN JA- WA DALAM NOVEL RADEN MANDASIA SI PENCURI DAGING SAPI KARYA YUSI AVIANTO PAREANOM
}

\author{
Nafisah \\ Akademi Komunitas Perkebunan Yogyakarta \\ nafisah.zamardi@mail.ugm.ac.id
}

Artikel diterima: 01 Juni 2020

Artikel direvisi: 13 Juli 2020

Artikel disetujui: 26 Agustus 2020

\begin{abstract}
Abstrak
Penelitian ini bertujuan mengungkap ideologeme yang terdapat di dalam novel Raden Mandasia Si Pencuri Daging Sapi. Analisis ideologeme novel ini menggunakan teori intertekstual Julia Kristeva. Kristeva mengungkap dua metode untuk melihat ideologeme, yakni menggunakan analisis suprasegmental dan analisis intertekstual. Analisis suprasegmental berfokus kepada teks (kata, frasa, dan kalimat) di dalam novel, sedangkan analisis intertekstual digunakan untuk melihat hubungan novel tersebut dengan teksteks historisnya. Penemuan ideologeme dengan memanfaatkan teks-teks historis, kemudian digunakan untuk membantu memproduksi makna novel Raden Mandasia Si Pencuri Daging Sapi. Novel ini memanfaatkan teks historis Babad Tanah Jawa. Dengan menggunakan cara pandang oposisi, transformasi, dan transposisi, maka ditemukan bahwa novel Raden Mandasia Si Pencuri Daging Sapi merupakan usaha Pareanom untuk mendesakralisasi dan mendelegitimasi konsep kepemimpinan Jawa.
\end{abstract}

\section{Abstract}

This study aims to uncover the ideologies contained in the novel Raden Mandasia Si Pencuri Daging Sapi. This novel ideological analysis uses Julia Kristeva's intertextual theory. Kristeva revealed two methods for seeing ideologeme, namely using suprasegmental analysis and intertextual analysis. Suprasegmental analysis focuses on the texts (words, phrases and sentences) in the novel, while intertextual analysis is used to see the novel's relationship with its historical texts. Ideologeme discoveries by utilizing historical texts, then used to help produce the meaning of the novel Raden Mandasia Si Pencuri Daging Sapi. This novel makes use of the historical text Babad Tanah Jawa. By using the perspective of opposition, transformation, and transposition, it was found that the novel Raden Mandasia Si Pencuri Daging Sapi was Pareanom's attempt to neutralize Javanese culture and delegitimize the concept of Javanese leadership.

Keywords: ideologeme, suprasegmental, intertextual, Julia Kristeva

\section{Pendahuluan}

Produksi karya kanon ke dalam novel populer menjadi fenomena tersendiri dalam kancah sastra Indonesia. Hal ini tidak benarbenar baru, dibuktikan dengan diterbitkannya Kitab Omong Kosong karya Seno Gumira Ajidarma pada tahun 2004. Novel ini terinspirasi dari kisah Ramayana. Kemudian, pada tahun-tahun selanjutnya, fenomena ini terus bergerak dengan diterbitkannya dwilogi Rahvayana: Aku Lala Padamu (2014) dan Rahvayana 2: Ada yang Tiada (2015) karya Sudjiwo Tejo yang terinspirasi dari kisah Ramayana juga, Raden Mandasia Si Pencuri Daging Sapi (2016) karya Yusi Avianto Pareanom yang terinspirasi dari Babad Tanah Jawa, dan Drupadi (2017) karya Seno Gumira Ajidarma yang terinspirasi dari kisah Mahabharata. 
Dari keberlanjutan penerbitan novel populer yang terinspirasi karya kanon tersebut, ada satu novel yang patut menjadi perhatian, yakni Raden Mandasia Si Pencuri Daging Sapi. Sejak diterbitkan pada tahun 2016, novel ini menjadi perbincangan hangat dan mendapat banyak pujian telak dalam diskusidiskusi sastra di media sosial. Sebagian besar para pembaca-untuk tidak menyebut keseluruhan-memberikan penilaian tinggi terhadap novel ini. Dalam ulasannya, mereka juga menyebut bahwa novel ini merupakan Babad Tanah Jawa versi modern.

Selain diakui sebagai novel dengan kelas 'tinggi' oleh masyarakat media sosial, novel terbitan Banana Publisher ini juga dinobatkan sebagai pemenang Kusala Sastra Khatulistiwa Kategori Prosa pada 2016. Sejak saat itu, diskusi-diskusi mengenai Raden Mandasia Si Pencuri Daging Sapi mulai menjamur di komunitas-komunitas sastra, salah satunya diskusi yang diselenggarakan oleh Post Santa (toko buku independen) di Jakarta Selatan pada tanggal 21 Maret 2016. Diskusi yang dihadiri langsung oleh Pareanom ini merupakan diskusi santai terkait tanggapan pembaca mengenai novel Raden Mandasia Si Pencuri Daging Sapi. Komentar pembaca menyasar beragam hal mengenai novel ini seperti kekhasan karakter tokoh, eksplorasi aspek kuliner, feminisme, bahkan ada yang meramalkan novel ini akan menjadi salah satu novel terbaik masa sekarang.

Yusi Avianto Pareanom merupakan sastrawan kelahiran Semarang yang sudah menerbitkan karya fiksi dan nonfiksi, di antaranya Rumah Kopi Singa Tertawa (2011), Grave Sin No. 14 and Other Stories (2015, terbit dalam tiga bahasa: Indonesia, Inggris, dan Jerman), Raden Mandasia Si Pencuri Daging Sapi (2016), dan Muslihat Musang Emas
(2017). Mantan jurnalis Tempo yang juga merupakan Ketua Komite Sastra Dewan Kesenian Jakarta periode 2015-2018 ini telah dekat dengan dunia sastra sejak kecil berkat bacaanbacaan yang diberikan oleh orang tuanya. Barubaru ini, ia juga terpilih sebagai penerima Beasiswa Unggulan dalam bentuk kegiatan residensi penulis ke Jepang yang diselenggarakan oleh Kementerian Pendidikan dan Kebudayaan dengan Komite Buku Nasional periode 2018. Melihat sepak terjang Pareanom dalam dunia kepenulisan, khususnya penulisan sastra, membuat pujian atas kelihaiannya mengolah Babad Tanah Jawa menjadi Raden Mandasia Si Pencuri Daging Sapi memang pantas diberikan.

Popularitas novel Raden Mandasia Si Pencuri Daging Sapi termuat pula dalam artikel berjudul "Indonesian Novels in the National Newspaper's Response of 2016" yang ditulis oleh Nurhadi Bewe, dkk. Artikel ini dimuat dalam International Journal of Literature and Arts volume 6, Juli 2018. Penelitian ini membahas fenomena ulasan terhadap novel Indonesia sepanjang tahun 2016 yang dimuat oleh mediamedia nasional di antaranya Kompas, Republika, Koran Tempo, Koran Sindo, dan Media Indonesia.

Hasil penelitian menyimpulkan bahwa terdapat empat novel fenomenal dari total 45 novel dan 51 ulasan di media nasional sepanjang tahun 2016. Keempat novel ini telah diulas di media nasional setidaknya sebanyak dua kali dan mendapatkan tanggapan positif dari setiap pengulas. Adapun keempat novel tersebut adalah Raden Mandasia Si Pencuri Daging Sapi karya Yusi Avianto Pareanom, Supernova: Intelegensi Embun Pagi karya Dewi Lestari, $O$ karya Eka Kurniawan, dan Tentang Kamu karya Tere Liye. Novel Raden Mandasia Si Pencuri Daging Sapi memiliki kuantitas ulasan terbanyak daripada novel lainnya, yakni sejumlah tiga kali. 
Poetika : Jurnal Ilmu Sastra

Vol. 8 No. 1, Juli 2020
DOI 10.22146 /poetika.56501

ISSN 2338-5383 (print) ; 2503-4642 (online)
Ulasan mengenai novel ini termuat dalam artikel berjudul "Perjalanan Dendam", "Sebelum Babad Tanah Jawa", dan "Kembalinya Genre Silat Kolosal". Novel Raden Mandasia Si Pencuri Daging Sapi disebut sebagai novel yang berhasil memuat cerita petualangan dari masa lalu, yakni Babad Tanah Jawa.

Ketika membaca Raden Mandasia Si Pencuri Daging Sapi, pembaca disodorkan namanama tokoh yang serupa dengan tokoh dalam Babad Tanah Jawa. Novel ini bercerita mengenai kisah Prabu Watugunung dengan dua puluh tujuh anak dan dua orang istrinya. Di dalam novel ini juga disuguhkan peperangan-peperangan ala cerita Babad Tanah Jawa. Konsep tentang ketampanan yang merupakan warisan turun-temurun keluarga bangsawan juga dipertahankan dalam novel ini. Cerita-cerita soal malapetaka, lelaki yang menikahi ibunya, dan peperangan tidak luput menjadi sorotan. Selain itu, tidak hanya dengan menduga-duga bahwa novel ini terinspirasi dari Babad Tanah Jawa-Pareanom pun mengklaim pada akhir cerita-bahwa bisa saja ceritanya ini ia beri judul Babad Tanah Jawa. Akan tetapi, ia takut judul tersebut akan membuat gusar banyak orang jika jadi digunakan.

Klaim Pareanom tersebut, tidak serta merta membuat Raden Mandasia Si Pencuri Daging Sapi persis sama dengan Babad Tanah Jawa. Ada tokoh-tokoh yang ditonjolkan, seperti Prabu Watugunung, 27 anaknya, dan kedua istrinya. Ada pula tokoh-tokoh penting di Babad Tanah Jawa yang dieksklusi seperti Brawijaya, Hayamwuruk, Senapati ing Ngalaga, Gajahmada, Ki Ageng Pemanahan, Sultan Hadijaya, Pangeran Banawa, Untung Surapati, Trunajaya, Kapten Tak, Arya Penangsang, Ratu Kalinyamat, Sunan Prawata,
Sunan Kudus, Sunan Giri, dan sebagainya.

Selain itu, ada cerita-cerita yang ditambahkan seperti dongeng-dongeng dari mancanegara di antaranya cerita Pinokio yang sama sekali tidak pernah disinggung di dalam Babad Tanah Jawa. Selanjutnya, juga terdapat cerita-cerita yang disubstitusi. Misalnya, dalam Babad Tanah Jawa, mitos-mitos menjadi hal yang dijunjung tinggi. Akan tetapi, di dalam novel Raden Mandasia Si Pencuri Daging Sapi, Pareanom tidak menonjolkan hal-hal tersebut.

Transformasi Babad Tanah Jawa ke dalam novel Raden Mandasia Si Pencuri Daging Sapi ini tentu dipengaruhi juga oleh perbedaan konteks sosial. Babad Tanah Jawa, yang ditulis pada tahun 1884, berpedoman pada konteks sosial yang berkembang pada zaman itu. Begitu pula Pareanom, di era yang sekarang ini, ia mulai tampak mengedepankan hal-hal logis dalam cerita olahannya. Ia mengeksklusi tokoh-tokoh, menambahkan cerita-cerita, dan mensubstitusi mitos-mitos.

Selain itu, dalam sebuah diskusi mengenai novel Raden Mandasia Si Pencuri Daging Sapi yang diadakan oleh Klub Baca Radio Buku dan dihadiri oleh pendirinya-Muhidin M. Dahlan-menyebut bahwa novel ini juga terpengaruh oleh Serat Centhini dan sastra Jawa lainnya. Kitab Pawukon juga bisa diasumsikan sebagai inspirasi novel Raden Mandasia Si Pencuri Daging Sapi karena tiga puluh tokoh utamanya sama persis dengan nama 30 wuku dalam kitab tersebut.

Asumsi-asumsi pembaca terhadap novel Raden Mandasia Si Pencuri Daging Sapi, sekiranya menjadi hal menarik untuk dikaji secara ilmiah. Diperlukan penemuan komponen-komponen dalam novel tersebut untuk membuktikan apakah benar keberagaman teks dalam novel Raden Mandasia Si Pencuri Daging Sapi dapat pula dilihat secara menyeluruh da- 
lam teks sosio historis yang telah disebut para pembaca. Maka dari itu, teori intertekstual Julia Kristeva dianggap cocok untuk melihat komponen-komponen teks-atau disebut Kristeva sebagai ideologeme-ini dan kemudian dapat dilanjutkan dengan memberikan pemaknaan terhadap bentuk-bentuk ideolegeme yang ditemukan.

Hal mendasar yang perlu dipahami dari teks menurut intertekstualitas Julia Kristeva, yaitu teks memiliki kesamaan nilai budaya dan historis dengan teks-teks lain sebelumnya. Lahirnya sebuah teks menurut Kristeva berporos pada faktor horizontal dan vertikal. Faktor horizontal berkaitan dengan konteks zaman (pembaca), sedangkan poros vertikal yaitu kekayaan khazanah cerita yang bisa dimanfaatkan oleh seorang pengarang. Selanjutnya, interseksi antara poros vertikal dan poros horizontal inilah yang disebut sebagai ideologeme.

Teks bukan merupakan individu yang terpisah, melainkan gabungan dari teks yang terdapat di dalam karya sastra dan teks yang terdapat di luar karya sastra, kedua komponen ini tidak dapat dihilangkan salah satunya. Teks juga tidak terlepas dari kondisi sosial budaya saat teks tersebut dibuat (Kristeva, 1980:36). Teks merupakan penyerapan dan transformasi dari teks lain (Kristeva, 1980:66). Dengan menduga bahwa sebuah teks merupakan reaksi, penyerapan, atau transformasi dari teks lain, maka intertekstualitas, sebagaimana prinsipnya, berusaha memahami dan memberikan makna terhadap sebuah teks.

Terdapat tiga proses untuk memberikan pemaknaan ideologeme suatu teks. Ketiga proses tersebut adalah oposisi, transposisi, dan transformasi (Kristeva, 1980 dalam Nasri, 2017:210). Oposisi merupakan sesuatu yang mutlak dan tidak dapat tukar menukar dalam dua kelompok yang saling bertentangan. Transposisi adalah perpindahan teks dari sistem tanda pertama ke sistem tanda yang baru. Transposisi mencakup empat hal yakni penambahan, pengurangan, penggantian, dan penyusunan kembali. Transformasi adalah perubahan bentuk dari satu teks ke teks yang lain. Hal ini dipahami sebagai teks yang dibaca penulis dapat berubah karena penulis menyisipkan dirinya saat menulis ulang teks tersebut.

Berikut eksplorasi terhadap novel Raden Mandasia Si Pencuri Daging Sapi dengan menggunakan perangkat analisis intertekstual Julia Kristeva.

\section{Kerajaan Gilingwesi}

Novel RMSPDS secara garis besar berkisah mengenai sebuah kerajaan besar yang dipimpin oleh seorang raja yang memiliki 27 anak kembar. Nama kerajaan besar ini adalah Gilingwesi yang digambarkan sebagai kerajaan yang kaya, luas, dan memiliki banyak daerah taklukan. Hal ini dapat dilihat dalam kutipan berikut.

Di Kotaraja Gilingwesi, segala sesuatu serba besar sepertinya. Jalanannya lebar-lebar, nyaris tiga puluh depa setiapnya. Jalan-jalan itu bersih karena setiap pagi dan siang hari ada petugas-petugas khusus yang menyirami sehingga debu tak beterbangan. Di bagian pusat kota, jalanan bukan lagi terbuat dari tanah yang dikeraskan, melainkan dari batu kali yang dipotong pipih. Taman-taman kotanya dua kali lipat luasnya atau bahkan lebih ketimbang yang ada di Banjaran Waru. Taman-taman itu juga lebih indah karena banyaknya tanaman hias di sana (Pareanom, 2016:113-114).

Kisah mengenai Kerajaan Gilingwesi dapat dilihat pula dalam Babad Tanah Jawa. Babad Tanah Jawa yang digunakan dalam penelitian ini adalah terjemahan M. Ramlan atas karya sastra Jawa yang berjudul Babad Tanah Djawi. Teks ini disunting oleh J.J. Meinsma dan diter- 
bitkan oleh S'Gravenhage, Martinus Nyhoff dalam dua jilid pada tahun 1884 dan 1899 menggunakan huruf Jawa. Kerajaan Gilingwesi disebut pertama kali untuk mengawali cerita lainnya mengenai sejarah raja di tanah Jawa. Kerajaan ini dipimpin oleh Watugunung. Ia memiliki dua orang istri bernama Dewi Sinta dan Dewi Landep. Dari perkawinannya dengan Dewi Sinta, ia memiliki putra sebanyak dua puluh tujuh orang di antaranya Wukil, Kurantil, Tolu, Gumbreg, Warigalit, Warigagung, Julungwangi, Sungsang, Galungan, Kuningan, Langkir, Mandasiya, Julungpujud, Pahang, Kuruwelut, Marakeh, Tambir, Medangkungan, Maktal, Wuye, Manahil, Prangbakat, Bala, Wugu, Wayang, Kulawu, dan yang terakhir Dukut (Meinsma, 1975:1).

Bencana-bencana yang menimpa Kerajaan Gilingwesi dipercaya sebagai pertanda kehancuran kerajaan besar itu. Adapun bencana tersebut di antaranya adalah rakyat mati kelaparan, sering terjadi gerhana matahari dan gerhana bulan, hujan turun terus menerus, dan intensitas gempa bumi yang tinggi (Meinsma, 1975:1). Nama Gilingwesi juga disebut sebagai salah satu nama kerajaan induk di nusantara pada zaman Sedang Kala Kukila.

Cerita mengenai Kerajaan Gilingwesi menunjukkan bahwa novel RMSPDS merujuk kepada satu kebudayaan yang eksklusif, yakni kebudayaan Jawa. Pengerucutan novel RMSPDS sebagai cerita yang berlatar kebudayaan Jawa, diperkuat dengan simbolsimbol lain seperti penggunaan senjata tradisional khas Jawa. Keris dijadikan sebagai senjata yang digunakan dalam peperangan di novel. Selain itu, Prabu Watugunung, sebagai raja sakti, digambarkan memiliki keris khusus yang dapat digunakan untuk me- lumpuhkan lawannya dengan mudah.

Saat ini keris masih ditemukan dalam kehidupan sehari-hari, tetapi sudah mengalami perubahan fungsi. Di zaman dahulu, sebagaimana yang dideskripsikan dalam novel, keris dijadikan sebagai senjata untuk berperang, sedangkan sekarang keris digunakan sebagai asesori ketika berbusana atau disimpan sebagai benda pusaka.

Penggunaan keris, kerambit, dan belati, juga didukung dengan kemampuan orang zaman dahulu mengolah racun. Racun dijadikan sebagai senjata tambahan yang mematikan. Selain itu, juga ditemukan penggunaan senjata peperangan yang lebih sederhana, yakni katapel dan batu. Penggunaan kedua senjata ini menunjukkan bahwa pada masa itu di Indonesiakhususnya tanah Jawa, teknologi pembuat senjata belum secanggih sekarang. Senjata-senjata juga belum diimpor dari luar negeri. Saat ini, pertempuran sudah menggunakan senjatasenjata modern seperti fosgen, senapan mesin, bom, dan lain-lain. Selain itu, berbeda dengan kegunaannya di masa lalu, katapel pada zaman sekarang juga sudah berubah fungsi menjadi permainan anak-anak.

Penggunaan keris sebagai senjata tradisional yang digunakan untuk berperang menunjukkan novel ini adalah teks yang terbatas, sesuai dengan konteks dan zamannya. Sebagaimana yang diuraikan sebelumnya, novel ini bercerita mengenai kebudayaan Jawa di zaman kerajaan, maka simbol keris sebagai alat peperangan mendukung komponen tersebut. Meski teks ini lahir di masa sekarang, ia tetap berada pada ruangnya, yakni Jawa di masa lampau.

\section{Keberpihakan pada Rakyat Kecil}

Novel RMSPDS memuat oposisi yang hierarkis antara bangsawan dan rakyat biasa. Bang- 
sawan digambarkan memiliki kharisma, ketampanan, kekayaan, dan hal-hal baik lainnya. Berlawanan dengan itu, rakyat biasa, diposisikan lebih rendah sehingga berusaha tunduk terhadap kesuperioran yang dimiliki bangsawan. Di dalam novel ini, keistimewaan yang dimiliki keluarga kerajaan tidak hanya dideskripsikan secara eksplisit, melainkan juga digambarkan lewat simbol-simbol seperti pemakaian kelat besi, kepemilikan logam emas, dan sebagainya.

Meski demikian, struktur hierarkis antara keluarga kerajaan dengan rakyat biasa tidak terjadi secara statis sejak awal hingga akhir cerita. Ada perlawanan-perlawanan yang dilakukan oleh rakyat biasa terhadap keluarga kerajaan. Perlawanan ini guna membalaskan dendam atas apa yang telah dilakukan keluarga kerajaan tersebut. Pada akhir cerita, Pareanom membalik posisi itu. Bangsawan diceritakan mati di medan pertempuran, sedangkan Sungu Lembu, sebagai representasi rakyat biasa, tetap hidup. Ia bahkan dapat kembali ke Kerajaan Gilingwesi untuk mengabarkan kekalahan mereka kepada istri-istri raja.

Oposisi ini menunjukkan bahwa novel RMSPDS, berpihak kepada rakyat kecil. Deskripsi-deskripsi yang inferior mengenai rakyat kecil, ternyata tidak serta merta membuatnya selalu kalah. Usaha-usaha yang dilakukan rakyat kecil dapat membantu mengubah nasibnya menjadi lebih baik.

\section{Kebodohan Pemimpin sebagai Sebab Mal- apetaka}

Di bagian akhir, novel RMSPDS menyajikan cerita soal seorang anak laki-laki yang menikah dengan ibunya. Pada awalnya, hubungan anak dan ibu ini tidak disadari oleh keduanya. Dewi Sinta mengetahui bah- wa Prabu Watugunung merupakan anaknya ketika ia mengusap kepalanya dan menemukan bahwa ada luka di sana. Ia teringat beberapa tahun yang silam, telah kehilangan seorang anak laki-laki karena marah begitu besar dan memukul kepala anak tersebut dengan centong nasi hingga berdarah. Sang anak kemudian pergi dan tidak pernah kembali.

Cerita mengenai lelaki yang menikahi ibunya sendiri dapat dilihat pula dalam teks historis berjudul "The Watugunung Story and the $\mathrm{Wu}$ kus" dalam Java and Modern Europe karya Ann Kumar. Kumar menyebut teks ini berasal dari elaborasi lebih lanjut terhadap Babad Tanah Jawa yang dilakukan oleh Cornets de Groot.

By supernatural means he or Batara Guru himself impregnated Dewi Sinta, who gave birth to a boy named Watu Gunung, who had no navel and a hard cranium. He grew amazingly fast, and one day when he had again asked his mother for rice, she hit him on the head with the ricespoon.... (Kumar, 1997:145).

Bagian awal teks "The Watu Gunung Story and the Wukus" bercerita mengenai kelahiran Watu Gunung dan kejadian saat ia dipukul dengan centong nasi oleh ibunya ketika meminta nasi. Selanjutnya, teks Kumar juga memuat secara detail nama-nama anak dari Watu Gunung dan Dewi Sinta yang berjumlah 27 orang. Hal ini dapat dilihat dalam teks berikut.

After an involved three-way conflict between Watu Gunung, Arsi Tama, and the ruler of Giling Wesi, Watu Gunung triumphed and became ruler of Giling Wesi; he married the two Dewis, though he was cursed by the former ruler of Giling Wesi to die the same violent death as he had. After a year Dewi Dara had twin sons named Raden Wukir and Raden Kurantil, after another year twins named Talu and Gumbreg; two more named Wari Galit and Wari Gagung [i.e. Wariga alit dan Wariga gung]; two more named Julung Pujud and Pahang, two named Kuru Welut and Marakeh, two named Tambir and Medangkungan; two named Maktal and Wuye; two named Manail and Prang Bakat, two named 
Bala and Wugu, two named Wayang and Kulawu; and finally a son named Dukut, making a total of 27 sons; thus totalling, with Watu Gunung and his two wives, 30 persons (Kumar, 1997:145-146).

Selanjutnya terdapat cerita mengenai kesadaran Dewi Sinta yang ternyata menikahi anaknya sendiri. Untuk menyelamatkan dirinya dan saudaranya dari situasi yang tidak mengenakkan tersebut, ia kemudian memutuskan untuk meminta Watu Gunung memperistri Dewi Sikandi. Hal ini dapat dilihat dalam kutipan berikut.

Now it transpired that Dewi Dara dicovered the scar on Watu Gunung's head and realised that she had married her own son, for Dewi Dara and Dewi Dari were actually no other than Dewi Sinta and Dewi Landep. To extricate themselves from this shameful situation they made a plan to get Watu Gunung to ask the gods to give him Dewi Sekandi as wife (at the time he asked, Batara Guru and Batara Wisnu were disputing which of them she should marry) (Kumar, 1997:146).

Teks ini kemudian menjadikan kisah Prabu Watugunung sebagai asal muasal lahirnya wuku yang berjumlah tiga puluh, sesuai dengan jumlah keluarga Prabu Watugunung. Ketiga puluh wuku ini memiliki kharakteristik khusus. Wuku berisi perhitungan atau semacam panduan untuk menjalankan aktivitas sehari-hari seperti mencari pekerjaan, berburu, memasang perangkap, dan sebagainya.

Kisah Prabu Watugunung yang menjadi asal muasal perhitungan wuku, juga terdapat dalam Babad Tanah Jawa. Prabu Watugunung digambarkan tidak mau pulang ke Gilingwesi karena sudah senang tinggal di surga. Ia kemudian menginginkan agar istri dan anakanaknya dipanggil ke surga untuk berkumpul dengannya. Permintaannya tersebut dikabulkan oleh Batara Guru. Maka, setiap hari Ahad, keluarga Prabu Watugunung di- panggil satu demi satu ke surga dan inilah yang menjadi asal muasal adanya wuku yang berjumlah 30 (Meinsma, 1975:4).

Jumlah wuku sebanyak tiga puluh tersebut, berganti selama tujuh hari. Maka dari itu, wuku akan mulai lagi ke perhitungan awal setelah 210 hari. Di masyarakat Jawa, wuku berfungsi untuk menentukan hari baik dan hari buruk. Perhitungan wuku dihitung menurut bertemunya dua hari dalam sistem pasaran yang terdiri dari lima hari di antaranya Legi, Pahing, Pon, Wage, dan Kliwon dengan hari dalam sistem mingguan yang terdiri dari tujuh hari yakni Minggu, Senin, Selasa, Rabu, Kamis, Jumat, dan Sabtu. Setiap satu wuku berumur tujuh hari sebagaimana inspirasi mengenai nama-nama wu$\mathrm{ku}$ yang datang dari cerita mengenai pengangkatan keluarga Prabu Watugunung ke surga yang dilaksanakan satu kali dalam seminggu. Tiga puluh wuku tersebut dimulai dari Wuku Sinta, kemudian diikuti dengan wuku sesuai dengan nama putra-putra Prabu Watugunung dan ditutup oleh Wuku Watugunung.

Dari ideologeme teks lelaki yang menikahi ibunya sendiri ini, dapat dilihat bahwa kisah Prabu Watugunung dalam novel RMSPDS merupakan teks yang terbatas karena tidak sampai pada perhitungan wuku sebagaimana kisah Prabu Watugunung yang ditemukan dalam teks -teks historis lainnya. Teks lelaki yang menikahi ibunya sendiri, dinarasikan ulang dengan tetap mempertahankan beberapa objek seperti centong nasi dan kepala yang berdarah. Ada satu hal menarik yang dapat diamati dari teks ini. Pernikahan antara Prabu Watugunung dengan ibunya-Dewi Sinta dan Dewi Landep, dideskripsikan sebagai sebuah ketidaktahuan.

Ketidaktahuan inilah yang pada akhirnya menyebabkan petaka bagi mereka, yakni kehancuran Kerajaan Gilingwesi. Seharusnya, sebagai seorang yang bijaksana, sebelum meni- 
kahi Dewi Sinta dan Dewi Landep, Prabu Watugunung terlebih dahulu menelusuri asal muasal perempuan yang akan dinikahinya. Akan tetapi, Prabu Watugunung tertutupi oleh nafsunya yang melihat Dewi Sinta sebagai perempuan yang sangat cantik sehingga tanpa pikir panjang langsung menikahinya. Dengan demikian, ideologeme ini dapat dimaknai sebagai pelajaran akan pentingnya pengetahuan oleh seorang pemimpin. Seorang pemimpin memiliki kewajiban untuk melek informasi dan pengetahuan. Kemalasan (kebodohan) ternyata berakibat buruk bagi diri pemimpin itu sendiri maupun rakyat yang dipimpinnya.

\section{Rasionalitas}

Novel RMSPDS, sarat akan mitos. Mitos yang dimaksud di sini diartikan secara sederhana sebagai cerita mengenai dewa-dewa dan hal gaib lainnya. Salah satu mitos yang dideskripsikan di dalam novel ini adalah mengenai asal mula kesaktian Watugunung. Dalam novel diceritakan kesaktian Watugunung didapatkan dari hasil persekutuan dengan dua jenis makhluk halus. Cerita mengenai asal muasal perkenalan Watugunung dengan makhluk halus adalah Watugunung melakukan pemujaan terhadap mereka dan bersedia menjadikan keluarganya sebagai tumbal saat hari penagihan tiba. Hal ini dapat juga dikenal sebagai pesugihan. Pesugihan merupakan hubungan kerja sama antara manusia dan jin atau makhluk gaib. Hubungan ini tidak bersifat cuma-cuma, melainkan seperti simbiosis mutualisme. Manusia yang melakukan pemujaan atau pesugihan, akan mendapatkan bantuan dari jin atas keinginannya. Di sisi lain, jin yang telah membantu manusia mewujudkan keinginannya, akan menagih tumbal sesuai keinginannya.

Istilah pesugihan berasal dari bahasa Jawa 'sugih' yang memiliki arti 'kaya'. Pesugihan dalam masyarakat Jawa memiliki sejarah panjang. Fenomena sosial ini sudah ditemukan sejak zaman Kerajaan Mataram sampai zaman kemerdekaan. Dalam beberapa kurun tahun terakhir, bahkan ditemukan praktik pesugihan palsu yang menipu banyak korban. Di dalam novel RMSPDS, disebutkan beberapa jenis makhluk halus untuk pesugihan di antaranya jaran penoleh atau kuda yang kepalanya menoleh ke belakang, srengara nyarap atau anjing menggigit, bulus jimbung atau bulus yang sangat besar, gemak melung atau burung puyuh yang bergelung, dan lain-lain.

Beberapa yang disebut oleh Pareanom dalam novelnya tersebut, ternyata merupakan jinjin yang populer di dunia pesugihan. Pertama, jaran penoleh, merupakan pesugihan yang terdapat di daerah perbatasan antara Jawa Barat dan Jawa Tengah. Di kawasan ini ada petilasan dalam bentuk makam kuda. Makam ini memiliki seorang juru kunci yang menjadi penghubung antara jin atau makhluk gaib dengan manusia yang ingin memujanya. Kedua, srengala nyarap merupakan wujud dari anjing gila yang suka menggigit. Ketiga, bulus jimbung merupakan wujud dari seekor bulus yang sangat besar. Keempat, kutuk lamur merupakan wujud dari ikan yang daya penglihatannya tidak jelas.. Kelima, gemak melung merupakan wujud gemak yang berkicau, dan lain-lain. Makhluk halus yang disebut Pareanom ini tergolong kepada makhluk halus jahat karena ia meminta tumbal sebagai balasan pertolongannya. Adapun makhluk halus yang baik, digambarkan akan membantu manusia tanpa meminta balasan apa pun.

Pemujaan yang dilakukan raja untuk mendapat kesaktian sebagaimana yang biasa 
dikenal dalam cerita pakem mengenai kesaktian Prabu Watugunung, dijelaskan secara berbeda dalam novel RMSPDS. Pareanom menolak cerita pakem tersebut dengan memberikan alasan-alasan logis mengenai asal muasal kesaktian yang sekiranya dapat diterima pembaca modern zaman sekarang, yakni dengan tekun berlatih. Dengan demikian, novel RMSPDS dapat disebut sebagai teks terbatas karena tidak sepenuhnya mengikuti cerita pakem soal pemujaan kepada makhluk halus, melainkan menentang hal tersebut.

Lebih lanjut, juga ditemukan idelogeme teks pertarungan antara Prabu Watugunung dengan Batara Wisnu. Ideologeme ini menunjukkan bahwa novel RMSPDS mengalami transformasi. Di dalam teks historis Babad Tanah Jawa, pertarungan antara Prabu Watugunung dengan Batara Wisnu dilakukan dengan menjawab teka-teki. Jika Batara Wisnu berhasil menjawab teka-tekinya, maka ia berhak memenggal kepala Prabu Watugunung. Akan tetapi, jika yang terjadi adalah sebaliknya, maka ia berhak menikahi bidadari di Suralaya. Batara Wisnu menyetujui hal tersebut. Teka-teki yang diberikan Watugunung ternyata dijawab dengan mudah oleh Batara Wisnu yang mengakibatkan Watugunung dipenggal kepalanya.

Hal tersebut menunjukkan bahwa kematian Watugunung adalah kematian yang konyol dan sia-sia. Ia terkesan tidak mau berjuang untuk meraih keinginannya. Harusnya, sebagai seorang yang sakti, ia mau berperang secara fisik dengan Batara Wisnu sampai tetes darah penghabisannya. Sebaliknya, jika memang menurutnya pertempuran dapat diganti dengan menjawab teka-teki saja, seharusnya Prabu Watugunung menyiapkan soal yang lebih sulit agar tidak dapat dijawab oleh
Batara Wisnu. Narasi yang demikian menunjukkan bahwa Prabu Watugunung adalah raja yang pemalas dan kurang ilmu.

Adapun transformasi yang ditemukan dalam novel RMSPDS adalah berupa penggantian metode pertarungan antara Prabu Watugunung dengan Batara Wisnu. Jika pada teks historis pertarungan dilakukan berupa menjawab tekateki, maka di dalam novel RMSPDS pertarungan dilakukan dengan peperangan besar-besaran. Prabu Watugunung melakukan persiapan yang matang, ia melatih pasukan, menyusun strategi, menyiapkan akomodasi yang memadai, barulah menuju Kerajaan Gerbang Agung untuk berperang. Hal ini menunjukkan bahwa novel RMSPDS lagi-lagi mengedepankan gagasan akan pentingnya ilmu dan kesungguh-sungguhan. Meskipun pada akhirnya Prabu Watugunung tetap mati, tapi kematiannya bukanlah kematian yang konyol karena ia sudah berusaha sekuat tenaga dan pikirannya untuk meraih keinginan. Kematian yang demikian, dapat lebih berterima dan dihargai dibanding kematian sia-sia karena memberikan teka-teki yang mudah ditebak lawan.

\section{Desakralisasi Kebudayaan Jawa}

Transformasi selanjutnya yang dapat ditemukan dalam novel RMSPDS adalah berupa penggantian teks lelaki yang ingin menikahi bidadari dengan teks lelaki yang ingin menikahi putri kerajaan. Di dalam teks historis, Prabu Watugunung digambarkan ingin menikahi bidadari-bidadari di suralaya, tetapi di dalam novel bidadari-bidadari tersebut diganti dengan seorang putri dari kerajaan besar bernama Gerbang Agung. Putri ini sangat cantik dan banyak yang sudah meminangnya tetapi tidak satu pun yang diterima.

Penggantian bidadari menjadi putri kerajaan ini, dimaknai sebagai usaha Pareanom 
agar novel ini lekat dengan kehidupan zaman sekarang. Raja yang meminang putri kerajaan dianggap lebih berterima di mata pembaca dibanding raja yang meminang bidadari. Hal ini menunjukkan konsistensi novel, dari awal hingga akhir, ia memperhatikan detail-detail mengenai kelogisan novel.

Selaras dengan transformasi yang ditemukan sebelumnya, terdapat pula penggantian teks penyerangan ke surga dengan teks penyerangan antarkerajaan. Di dalam teks historis, Prabu Watugunung digambarkan melakukan penyerangan ke surga untuk dapat menikahi bidadari. Akan tetapi, di dalam novel surga diganti dengan Kerajaan Gerbang Agung. Penggantian surga menjadi Kerajaan Gerbang Agung bukanlah penggantian yang semena-mena. Pareanom menyelipkan tanda-tanda yang menunjukkan bahwa Kerajaan Gerbang Agung adalah surga, misalnya dengan deskripsi bahwa Kerajaaan Gerbang Agung memiliki tujuh lapis tembok yang besar-besar, sebagaimana surga yang memiliki tujuh tingkatan.

Selanjutnya, Prabu Watugunung dikisahkan melawan dewa-dewa di surga dalam Babad Tanah Jawa. Hal ini menunjukkan bahwa Watugunung sebagai manusia, beroposisi dengan dewa sebagai Tuhan. Pertarungan antara mereka berujung pada kekalahan Watugunung. Pertentangan ini kemudian menjadi pertentangan yang hierarkis karena dewa digambarkan lebih tinggi, lebih kuat dan Watugunung, sebagai manusia, digambarkan lebih rendah, lebih lemah.

Oposisi yang hierarkis ini, kemudian ditransformasi dalam novel RMSPDS. Relasi oposisi antara Prabu Watugunung sebagai manusia dengan dewa-dewa di Suralaya diganti dengan relasi oposisi antara Prabu Watugunung dengan Pangeran Awatara yang merupakan perwakilan kerajaan Gerbang Agung.

Kehadiran Pangeran Awatara ini tidak serta merta sebagai penggantian yang sembarang, tetapi Pareanom menyisipkan simbol-simbol bahwa Pangeran Awatara adalah dewa versinya. Simbol-simbol tersebut dapat dilihat dari pemilihan nama Awatara yang dikenal juga sebagai manifestasi Tuhan atau Dewa Wisnu yang turun ke bumi.

Selain itu, Pareanom juga mendeskripsikan bahwa senjata yang dimiliki oleh Pangeran Awatara adalah cakram emas. Cakram emas tersebut, dalam sumber di daring mengenai dewa-dewa, merupakan salah satu kekhasan yang dimiliki oleh Dewa Wisnu. Dewa Wisnu digambarkan selalu memegang empat benda yakni terompet kulit kerang, cakram atau senjata berputar dengan gerigi tajam, Gada yang bernama Komodaki, dan bunga Lotus atau Padma sebagai simbol kebebasan.

Dengan demikian, penggantian Batara Wisnu menjadi Pangeran Awatara, ketika dilihat secara menyeluruh dengan teks historisnya, menunjukkan bahwa novel ini lagi-lagi berusaha mematerialkan hal-hal yang gaib seperti Tuhan, surga, dan bidadari menjadi hal-hal konkret yang bersifat duniawi seperti raja, kerajaan, dan putri kerajaan.

\section{Delegetimasi Konsep Kepemimpinan Jawa}

Novel RMSPDS juga berbicara mengenai konsep kepemimpinan. Kepemimpinan yang dimaksudkan di sini adalah bagaimana pandangan novel ini terhadap persyaratan menjadi raja. RMSPDS mengemukakan narasi bahwa rakyat jelata dapat menjadi pemimpin, asalkan ia memiliki bekal yang cukup dengan tekun berlatih dan belajar. RMSPDS menolak bahwa pemimpin harus memiliki darah keturunan pemimpin pula. 
... Tapi, aku percaya bahwa suatu saat anak petani atau tukang kayu bisa menjadi pemimpin negeri ini kalau ia memang cakap. Mungkin awalnya akan lebih mudah jika pemimpin yang muncul masih punya garis keturunan raja. Nanti pasti akan muncul kerabat istana yang berhaluan sama dengan kita. Siapa tahu kau nanti yang jadi pemimpin kami, Sungu Lembu."

Cuping hidungku langsung membesar. Tapi, gagasan anak orang biasa menjadi pemimpin bagiku terasa asing dan aku benar-benar merasa usia tua telah merampas nyali pamanku (Pareanom, 2016:98-99).

Narasi yang demikian, tampaknya berbeda dengan yang ditemukan dalam teksteks historis mengenai konsep kepemimpinan Jawa. Di dalam Babad Tanah Jawa, diceritakan mengenai asal muasal raja-raja Jawa. Adapun yang menjadi Raja biasanya adalah keturunan raja pula. Konsep kepemimpinan Jawa, salah satunya terpusat kepada masalah keturunan. Menurut Koentjaraningrat (dalam Sofyan, 2010:29-31), terdapat hubungan antara seksualitas dengan kekuasaan dalam pemikiran Jawa, yakni adanya gagasan bahwa mani manusia, terutama mani seseorang yang mempunyai kekuasaan, merupakan suatu pemusatan kekuasaan tersendiri dan merupakan alat untuk mewariskannya.

Pertahanan secara kontiniu terhadap kepemimpinan kerajaan yang berdasarkan keturunan, harus dikuatkan lagi dengan keyakinan bahwa garis keturunan dapat ditarik lebih jauh lagi kepada dewa-dewa sehingga wewenang yang berdasarkan keturunan tadi tidak hanya merupakan wewenang yang kuat, tetapi juga keramat. Wewenang seorang raja atau pemimpin tradisional yang berdasarkan sifat kekeramatan itu perlu dijaga kemantapannya secara kontiniu dengan berbagai upacara intensifikasi. Dalam upacara tersebut benda-benda lambang kewibawaan dan wewenang raja serta pusaka-pusaka kerajaan yang keramat, mendapat fungsi yang penting bagi kekuasaan (Sofyan, 2010:29-30).

Hal ini kemudian menjadi satu benang merah di dalam novel RMSPDS, narasi baru mengenai konsep kepemimpinan yang tidak menjadikan garis keturunan sebagai faktor kunci, didukung pula dengan penghapusan segala simbol mengenai dewa-dewa dan surga yang terkesan keramat yang dijadikan sebagai alat untuk menjaga kekeramatan garis keturunan.

Simbol-simbol tersebut diganti menjadi hal -hal yang bersifat duniawi, keseharian, dan tidak memiliki kekuatan khusus. Dengan demikian, terjadi persamarataan antara orang yang memiliki garis keturunan pemimpin dengan orang yang tidak memiliki garis keturunan pemimpin. Hal yang kemudian membedakan mereka adalah, sebagaimana yang telah disebut-sebut sebelumnya, bekal pengetahuan dan usaha serta kerja keras untuk mencapai kepemimpinan yang diinginkan.

\section{Simpulan}

Berdasarkan uraian di atas, terdapat beberapa kesimpulan sebagai berikut. Pertama, analisis suprasegmental dan interteksual terhadap novel RMSPDS menemukan bahwa ideologeme novel ini adalah teks Kerajaan Gilingwesi, lelaki yang menikahi ibunya sendiri, pemujaan kepada makhluk halus untuk mencapai keinginan, lelaki yang ingin menikahi putri kerajaan, dan pertempuran dengan pangeran. Ideologeme yang ditemukan ini menunjukkan bahwa novel RMSPDS merupakan teks terbatas yang eksklusif berbicara mengenai budaya Jawa. Selanjutnya, jika melihat novel RMSPDS secara menyeluruh, komponenkomponen tersebut memanfaatkan teks-teks 
Poetika : Jurnal Ilmu Sastra

Vol. 8 No. 1, Juli 2020
DOI 10.22146 /poetika.56501

ISSN 2338-5383 (print) ; 2503-4642 (online) historis di antaranya Babad Tanah Jawa dan teks "The Watu Gunung Story and the Wukus". Pemanfaatan teks-teks historis ini kemudian digunakan untuk memberikan makna novel RMSPDS.

Kedua, oposisi yang ditemukan antara keluarga kerajaan dan rakyat biasa menunjukkan bahwa novel RMSPDS berpihak kepada kehidupan rakyat kecil. Adapun transformasi dan transposisi yang ditemukan dalam novel RMSPDS menunjukkan bahwa novel RMSPDS merupakan delegitimasi konsep kepemimpinan Jawa yang mengukuhkan bahwa raja harus bersifat turun temurun, yang berhak menjadi raja adalah keturunan bangsawan. RMSPDS membawa narasi baru bahwa kebangsawanan bukanlah faktor utama penentuan seseorang untuk menjadi pemimpin. Pemimpin dapat berasal dari mana saja, termasuk rakyat kecil sekali pun.

Selanjutnya, konsep kepemimpinan Jawa, juga memberikan perhatian khusus kepada hal-hal yang sakral seperti dewa, Tuhan, dan benda-benda keramat. Hal ini juga ditolak dalam novel ini. Semua hal sakral tersebut dimaterialkan menjadi hal-hal bersifat duniawi sehingga tidak memiliki kekuatan kosmis khusus. Dengan demikian, novel ini dapat pula disebut sebagai usaha Pareanom untuk mendesakralisasi konsep kepemimpinan Jawa. Selain itu, novel ini juga dapat dimaknai sebagai kritik terhadap budaya atau konsep kepemimpinan Jawa yang masih menjunjung tinggi ramalan-ramalan atau penanggalan-penanggalan. Hal ini disubstitusi dengan bekerja keras, berlatih, atau menempuh pendidikan yang baik.

Beberapa hal yang diuraikan di atas, jika dilihat dalam konteks zaman sekarang, menjadi relevan sebab pada suatu masa dalam pemerintahan Indonesia, pernah ada pem- impin yang bukan dari kalangan bangsawan sehingga meruntuhkan tradisi yang telah berjalan sebelumnya di mana pemimpin selalu berasal dari trah bangsawan atau pemimpin pula.

\section{Daftar Pustaka}

Kristeva, Julia. 1980. Desire in Language: A Semiotic Approach to Literature and Art. Oxford: Basil Blackwell.

Kumar, Ann. 1997. Java and Modern Europe. Britania Raya: Routledge.

Meinsma, J.J. 1975. Babad Tanah Jawa. Diterjemahkan oleh M. Ramlan. Kuala Lumpur: Percetakan Dewan Bahasa dan Pustaka.

Pareanom, Yusi Avianto. 2016. Raden Mandasia Si Pencuri Daging Sapi. Depok: Banana.

Sofyan, Yusep Munawar. 2010. "Kekuasaan Jawa: Studi Komparatif Sistem Kekuasaan Kerajaan Majapahit dan Demak". Skripsi. Jakarta: UIN Syarif Hidayatullah.

\section{Daftar Laman}

http://narasastra.wixsite.com/narasastra/ single-post/2016/03/21/Bincang-RadenMandasia-di-POST-Santa. Diakses pada 27 November 2018 pukul 00.18 WIB

https://bpmfpijar.com/2017/03/05/radiobuku-mengadakan-diskusi-novel-radenmandasia/. Diakses pada 15 Januari 2019 pukul 11.36

http://www.dewisundari.com/pesugihandalam-kebudayaan-jawa/. Diakses pada 18 Juni 2019 pukul 19.07 wib

http://kumbercer.blogspot.com/2016/07/ pesugihan-jaran-penoleh.html. Diakses pada Kamis, 16 Mei 2019 pukul 15.53 wib

https://kumparan.com/creeps/9-makhluksumber-pesugihan. Diakses pada Kamis, 16 Mei 2019 pukul 16.03

https://www.keajaibandunia.web.id/1027/ mengenal-lebih-dekat-tentangnusantara.html. Diakses pada 18 Juni 2019 pukul 08.18 wib

http://narasastra.wixsite.com/narasastra/ single-post/2016/03/21/Bincang-RadenMandasia-di-POST-Santa diakses pada 27 November 2018 pukul 00.18 WIB 
Ulasan ini ditulis oleh Hera Khaerani yang termuat dalam Media Indonesia edisi 24 April 2016.

Ulasan ini ditulis oleh Arif F. Kurniawan yang termuat dalam koran Tempo edisi 7 Agustus 2016.

Ulasan ini ditulis oleh Teguh Efendi yang termuat dalam Kompas edisi 26 November 2016.

https://bpmfpijar.com/2017/03/05/radiobuku-mengadakan-diskusi-novel-radenmandasia/ diakses pada 15 Januari 2019 pukul 11.36

https://www.keajaibandunia.web.id/1027/ mengenal-lebih-dekat-tentangnusantara.html diakses pada 18 Juni 2019 pukul 08.18 wib http://www.dewisundari.com/pesugihandalam-kebudayaan-jawa/ diakses pada 18 Juni 2019 pukul 19.07 wib

http://kumbercer.blogspot.com/2016/07/ pesugihan-jaran-penoleh.html diakses pada Kamis, 16 Mei 2019 pukul 15.53 wib https://kumparan.com/creeps/9-makhluksumber-pesugihan diakses pada Kamis, 16 Mei 2019 pukul 16.01 wib

https://kumparan.com/creeps/9-makhluksumber-pesugihan diakses pada Kamis, 16 Mei 2019 pukul 16.01 wib https://kumparan.com/creeps/9-makhluksumber-pesugihan diakses pada Kamis, 16 Mei 2019 pukul 16.02 wib

https://kumparan.com/creeps/9-makhluksumber-pesugihan diakses pada Kamis, 16 